\title{
Non-linearity of insulin kinetics
}

Dear Sir,

Non-proportionality between plasma concentration and plasma disappearance rate of insulin in normal subjects was first reported by Sönksen and coworkers in 1973 [1]. The issue has since been controversial [2-6]. A recent paper by deFeo et al. [7] in Diabetologia addresses the problem in Type 1 (insulin-dependent) diabetic patients. The authors conclude from intravenous insulin infusions at three rates $\left(0.13,0.20\right.$ and $0.40 \mathrm{mU} \times \mathrm{kg}^{-1} \times \mathrm{min}^{-1}$ corresponding to 0.0008 , 0.0012 and $0.0025 \mathrm{nmol} \times \mathrm{kg}^{-1} \times \mathrm{min}^{-1} ; 1 \mathrm{nmol}=162 \mathrm{mU}$ ) that the metabolic clearance rate of insulin is independent of plasma insulin concentration at the narrow concentration range studied $(10-40 \mathrm{mU} / 1$ or $0.06-0.25 \mathrm{nmol} / \mathrm{l})$. The same conclusion was reached by Frost and coworkers [8] from four-step insulin infusions at the concentration range $5-300 \mathrm{mU} / 1(0.03-1.9 \mathrm{nmol} / 1)$. Thus, divergent results exist between normal subjects and Type 1 diabetic patients.

A straightforward way to answer the question whether the plasma disappearance rate of insulin is proportional to the insulin concentration (i. e. linearity of the insulin system) is constant infusion of insulin to different levels of steady state plasma insulin concentrations. We did two series of such experiments in normal subjects and Type 1 diabetic patients employing (a) insulin infusion rates to physiological ( $<300 \mathrm{mU} / 1$ or $1.9 \mathrm{nmol} / \mathrm{l}$, [6] and supraphysiological insulin levels, (b) normoglycaemia and (c) appropriate model validation procedures [9]. Data from these studies are summarized in Figure 1. In normal subjects, we could demonstrate existence of only saturable mechanisms at both physiological (unpublished data) and supraphysiological [5] insulin levels. In Type 1 diabetic patients, linearity existed at lower insulin concentrations (unpublished data); however, the minimal acceptable model included saturation kinetics alone in most diabetic patients at higher insulin levels [10]. The median metabolic clearance rate of insulin at low (physiological) insulin concentrations was $27 \%$ lower in diabetic patients $\left(19 \mathrm{ml} \times \mathrm{kg}^{-1} \times \mathrm{min}^{-1}\right)$ than in normal subjects $\left(26 \mathrm{ml} \times \mathrm{kg}^{-1} \times \min ^{-1}\right)(2 p<0.0005$ by the Mann-Whitney test). Clearance values of the same magnitude have been reported by others in man $[1,8]$ and dog [11-13].

Thus, both qualitative and quantitative differences in insulin kinetics emerge between normal subjects and Type 1 diabetic patients within the physiological insulin concentration range when insulin kinetics are studied by this straightforward methodology. The issue is of considerable importance [6], because saturability of insulin kinetics

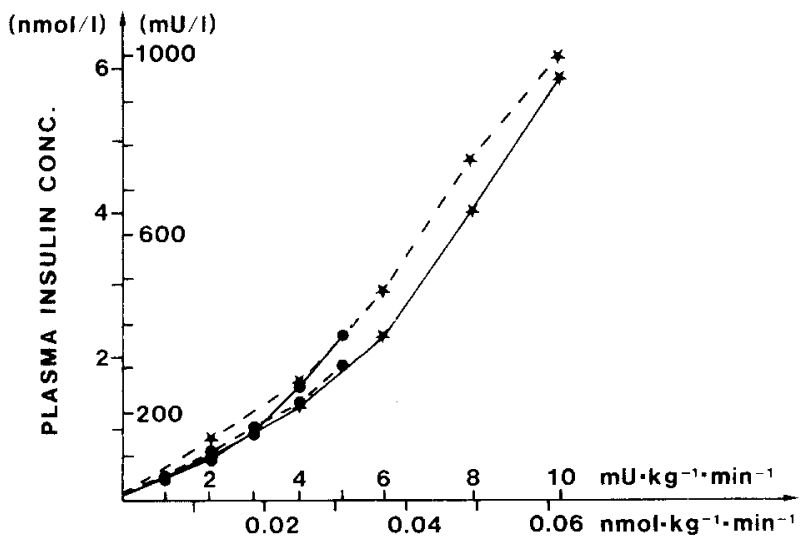

INSULIN INFUSION RATE

Fig. 1. Insulin concentration versus infusion rate in normal subjects and Type 1 diabetic patients during normoglycaemic glucose clamp. Mean data from experiments in $\operatorname{six}\left(*{ }^{*}\right)$ and eight $\left({ }_{-}^{*}\right)$ ) normal subjects and in six (*---.*) and twelve (-----) diabetic patients. Data are linearly interpolated invalidates studies based upon the assumption of the existence of first order kinetics. Other groups have failed to demonstrate saturation kinetics in normal subjects, probably due to the narrow range of insulin levels studied. The narrower the range, the more linear the system appears, and the more difficult will any demonstration of non-linearity be due to signal-to-noise ratio problems. By analogy, the horizon seems linear but the world is round.

Sincerely yours,

B. Thorsteinsson, S. Fugleberg and C. Binder

\section{References}

1. Sönksen PH, Tompkins CV, Srivastava MC, Nabarro JDN (1973) A comparative study on the metabolism of human insulin and porcine proinsulin in man. Clin Sci Mol Med 45: 633-654

2. Sherwin RS, Kramer KJ, Tobin JD, Insel PA, Liljenquist JE, Berman M, Andres R (1974) A model of the kinetics of insulin in man. $\mathrm{J}$ Clin Invest 53: 1481-1492

3. Fugleberg S, Kølendorf K, Thorsteinsson B, Bliddal H, Lund B, Bojsen F (1982) The relationship between plasma concentration and plasma disappearance rate of immunoreactive insulin normal subjects. Diabetologia 22: 437-440

4. Jones RH, Sönksen PH, Boroujerdi MA, Carson ER (1984) Number and affinity of insulin receptors in intact human subjects. Diabetologia 27: 207-211

5. Thorsteinsson B, Fugleberg S, Feldt-Rasmussen B, Binder C (1985) Kinetic models for plasma disappearance of insulin in normal subjects. Acta Pharmacol Toxicol 57: 309-316

6. Cobelli C, Mari A, Ferrannini E (1986) On linearity of insulin kinetics. Am J Physiol (Endocrinol Metab) E247-E248

7. DeFeo P, Perriello G, Venture MM, Calcinaro F, Basta G, Lolli G, Cruciani C, Dell'Olio A, Santeusanio F, Brunetti P, Bolli GB (1986) Studies on overnight insulin requirements and metabolic clearance rate of insulin in normal and diabetic man: relevance to the pathogenesis of the dawn phenomenon. Diabetologia 29: 475-480

8. Frost DB, Srivastava MC, Jones RH, Nabarro JDN, Sönksen PH (1973) The kinetics of insulin metabolism in diabetes mellitus. Postgrad Med J 49: 949-954

9. Carson ER, Cobelli C, Finkelstein L (1983) The mathematical modeling of metabolic and endocrine systems. Wiley, New York, pp: $1-394$

10. Thorsteinsson B, Fugleberg S, Feldt-Rasmussen B, Ellemann K, Andersen OO, Binder C (1986) Kinetic models for insulin disappearance from plasma in type I diabetic patients. Acta Pharmacol Toxicol (in press)

11. Franckson JRM, Ooms HA (1973) The catabolism of insulin in the dog: evidence for the existence of two catabolic pathways. Postgrad Med J 49: 931-939

12. Polonsky K, Jaspan J, Emmanouel D, Holmes K, Moossa AR (1983) Differences in the hepatic and renal extraction of insulin and glucagon in the dog: evidence for saturability of insulin metabolism. Acta Endocrinol 102: 420-427

13. Morishima T, Bradshaw C, Radziuk J (1985) Measurment using tracers of steady-state turnover and metabolic clearance of insulin in dogs. Am J Physiol (Endocrinol Metab) E203-E208

Dr. B. Thorsteinsson

Steno Memorial Hospital

Niels Steensensvej 2

DK-2820 Gentofte

Denmark 